\title{
Beden Eğitimi ve Sporda Perspektif Alma Etkinliklerinin Lise Öğrencilerinde Bakış Açısı Alma Becerileri Üzerine Etkisi
}

\author{
Merve IŞIKCI ${ }^{1}$ (D) , Gülfem SEZEN-BALÇIKANLI ${ }^{2}$ (D) \\ ${ }_{1}$ Yaşar Doğu Ortaokulu, MEB, ANKARA \\ ${ }^{2}$ Gazi Üniversitesi, Spor Bilimleri Fakültesi, ANKARA
}

Araştırma Makalesi

DOI:10.53434/gbesbd.992416

Öz

Çalışmanın amacı, Beden Eğitimi ve Sporda 'perspektif alma' etkinliklerinin, lise öğrencilerinin bakış açısı alma becerilerine etkisini incelemektir. Bu doğrultuda, araştırmacılar tarafindan Sporda Perspektif Alma Eğitim Programı oluşturulmuş ve bu program, araştırmacı tarafından öğrencilere beden eğitimi derslerinde 10 hafta boyunca uygulanmıștır. Araștırma grubu, 2017-2018 eğitim öğretim yılında Cihanbeyli/Konya'da bir Anadolu Lisesi'nde 9. sınıfta öğrenim gören 22 öğrenciden oluşmaktadır. Bakış açısı alma beceri düzeyi Kişilerarası Tepkisellik İndeksi'nin "perspektif alma alt boyutu" ile ölçülmüştür. Araştırmada Wilcoxon Testi ve Mann Whitney U Testi kullanılmıștır. Elde edilen bulgulara göre; eğitim sonrası perspektif alma puanının, eğitim öncesi perspektif alma puanına göre anlamlı derecede yüksek olduğu görülmektedir. Perspektif alma ön test-son test puanları bakımından cinsiyetler arasında istatistiksel olarak anlaml farklılı bulunmamaktadır. Perspektif alma etkinliklerinin, öğrencilerin olaylara karşısındakinin bakış açısından bakabilme becerisi sağlayacağı ve bu bağlamda akran zorbalığı, arkadaşlarına yönelik fiziksel ya da psikolojik şiddet, antisosyal davranışlar gibi olumsuz davranış özelliklerini en aza indirmek konusunda katkısı olacağı düşünülmektedir.

Anahtar sözcükler: Beden eğitimi ve spor, Empati, Perspektif alma, Bakış açısı alma becerisi 


\title{
The Effects of Perspective Taking Activities In Physical Education and Sports on High School Students' Perspective Taking Skills
}

\begin{abstract}
The aim of the study is to investigate the effects of perspective taking activities in physical education and sport on high school students' perspective taking skills. In this regard, Perspective Taking Training Program was developed by the researchers and were applied to students on physical education course

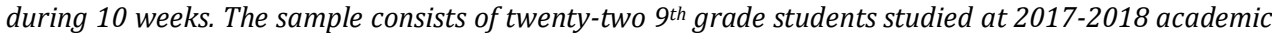
year in an Anatolian High School in Cihanbeyli, Konya. Experimental design was used for the current study. Perspective taking skill level was assessed by perspective taking subscale from "The Interpersonal Reactivity Index". Wilcoxon and Mann Whitney U tests were also used in the current study. According to the results, it was found that there is a significant increase in perspective taking scores of students after they completed training program. As a results, it can be interpreted that perspective taking activities applied in physical education and sports courses have some influences on students' perspective taking skills. It is assumed that perspective taking activities reduce to likelihood of experiencing and showing peer bullying, having antisocial behaviours and conducting physical or psychological violence towards friends because these activities provide some skills of taking others' perspectives in any cases.
\end{abstract}

Keywords: Physical education and sports, Empathy, Perspective taking, Perspective taking skill

\section{Giriş}

Bireylerin birbirleriyle olan ilişkilerinde ortaya çıkan sorunların giderilmesinde olaylara karşısındakinin bakış açısıyla bakmak, hoşgörülü olmak ve karşılıklı empati kurmak önemli bir yer tutmaktadır. İletişimde empatinin sağlıklı bir biçimde kurulabilmesi için, olaylar karşısındaki duygu ve düşüncelerin karşı tarafa doğru olarak aktarılması ve kişi tarafından da karşı tarafın bakış açısının doğru olarak anlaşılması büyük önem arz etmektedir (Özodaşık, 2009). Empatinin kritik bir bileșeni olan bakış açısı alma ise, kişinin var olan bilgiyi kullanarak diğer kişi hakkında doğru sonuca varmasını ve kendi görüşlerini diğer kişinin görüşlerinden ayırmasını sağlayan beceriler bütünü olarak tanımlanmaktadır (Zhao, Wang, Su ve Chan, 2010). Bu bağlamda, bireylerle olan iletişim durumlarında -onun gibi olmak, onun gibi düşünmek- iletişimi kolaylaştırmaktadır. Benzer şekilde, empatik düşünce yapısının gelişmiş olduğu bireyler farklı duygu ve düşünce yapılarına açık olmakta ve daha kolay iletişim kurmaktadırlar. Bu bireyler çoğunlukla demokratik tutum ve davranış sergileyen bireylerdir (Özodaşık, 2009). Diğer bir yandan, kişinin doğru bir şekilde bakış açısı alabilmesi için benmerkezcilikten uzaklaşması gerekmektedir. Çünkü benmerkezci düşünce, empatik yaklaşımın ve tutumun gelişmesinin önündeki engellerden biri olarak kabul edilmektedir (Dökmen, 2008).

Benmerkezcilik, Piaget'nin bilişsel gelişim kuramının temelinde yer alan önemli kavramlardan biridir. Piaget'ye (1965) göre, merkezden uzaklaşma becerisinin ortaya çıktığı yedi yaşına kadar bakış açısı alma becerisinin gelişimi mümkün değildir. Bu konuda yapılan çalışmalar, Piaget'nin aksine çocukların 2-3 yaşından itibaren başkalarının bakış açılarını anlayabildikleri sonucuna ulaşmaktadır (Aslan, 2017; Frick, Möhring ve Newcombe, 2014; Klahr, 2012). Yine de çocukların benmerkezci düşünceden tamamen 
uzaklaşabilmesi için yeterli bilişsel ve sosyal olgunluğa erişebilmesi kritiktir. Çünkü benmerkezci düşünce, iletişim çatışmaları ve daha ileri seviyede saldırganlığa neden olabilmektedir. Saldırganlık, kişilerin kendisine veya başkalarına zarar veren davranışlarda bulunması olarak ifade edilmektedir. Bu bağlamda, çocukluk ve ergenlik döneminde ortaya çıkan çatışma ve olumsuzlukların önlenmesi ve giderilmesi konusunda beden eğitimi ve sporun değerinin göz ardı edilemeyeceği belirtilmektedir (Dervent, Arslanoğlu ve Şenel, 2010). Yapılan çalışmalar, beden eğitimi ve sporun bireylerin fiziksel, bilişsel, duygusal ve sosyal gelişmelerini pozitif yönlü etkilediğini ve bu yönde davranışları artırma sürecinde büyük öneme sahip olduğunu göstermektedir (Bailey, 2006; İlhan, 2008; Opstoel ve diğerleri, 2020; Sezen-Balçıkanlı, 2014; Sezen-Balçıkanlı ve Sezen, 2017; SezenBalçıkanlı ve Yıldıran, 2012; Shima ve diğerleri, 2021). İnsan doğasında bulunan otoriteye başkaldırma, baskıya karşı dik durma gibi davranışlara neden olabilen hırs gibi duygular, spor faaliyetleri sırasında olumlu yönde kullanılabilmektedir. Benzer şekilde beden eğitimi ve spor, çocuk ve gençlere, toplum içinde otokontrol sağlayarak, davranışlarını ve heyecanlarını denetlemeyi öğretmektedir. Kazanma, kaybetme, rekabet gibi yoğun duyguların gelişimi ve yerleşmesi beden eğitimi ve spor ile sağlanmaktadır (Kaplan ve Çetinkaya, 2010). Ayrıca beden eğitimi ve sporda ahlak anlayışı, spordaki iyi ve kötü davranışlar temel alınarak değerlendirilirse; iyi davranışlar fırsat eşitliğini koruma, rakibi düşman olarak görmeme, haksız avantajlardan yararlanmama, iş birliğine ve takım arkadaşlığına yönelik davranabilme, empati kurabilme gibi davranışlarla bireylerin ahlaki gelişimini desteklemektedir (Sezen-Balçıkanlı, 2017). Ayrıca, Koçak ve Sezen-Balçıkanlı (2021) elit sporcularda empati becerilerini inceledikleri araştırmalarında, taekwondo sporuyla ilgilenen sporcuların daha erken yaşlarda bu spora yönelmelerinin de etkisiyle kickboks sporuyla ilgilenen sporculara göre empatik düşüncelerinin daha yüksek düzeyde olduklarını saptamışlardır. Erken yaşlarda farklı disiplin ve felsefeyi içinde barındıran bir spora yönelmenin, bireylerin empati gelişimlerine olumlu katkılar sağladığı düşünülmektedir.

Beden eğitimi ve sporun bireyler üzerindeki pozitif etkilerini gösteren çalışmaların aksine, literatürde var olan bazı çalışmalar beden eğitimi dersinde daha az yetenekli olan öğrencilerin takıma alınmadığını ve ilerleyen zamanlarda akran zorbalığına maruz kalabileceğini göstermektedir (Gessmann, 1985; Kähler, 1985; Ünlü ve Aydos, 2008). Bakış açısı almada yaşanan eksiklik sebebiyle ortaya çıkan bu sorun, olumsuz tutuma maruz kalan kișinin beden eğitimi ve spordan uzaklaşmasına sebep olabilmektedir. Yıldırım'ın (2012) çalışması, okullarda yaygın olarak görülen akran zorbalığının beden eğitimi ve spor derslerinde önlenmesi amacıyla grubun başarısını olumsuz etkileyen ve zorbalığa maruz kalan öğrenciye bir şans verilip, hazırlık maçlarına katılması sağlanarak öğrencinin neler yapabildiğini ortaya çıkarmanın doğru olduğunu vurgulamaktadır.

Bu bağlamda beden eğitimi ve sporda kullanılan bakış açısı alma etkinliklerinin akran zorbalığını azaltacağı ve öğrencilerin olay ve durumlara, karşısındakinin perspektifinden bakabilmesini sağlayacağı düşünülmektedir. Bu becerilerin öğrencilere kazandırılmasında, beden eğitimi dersinde uygulanan empati etkinliklerinin önemli bir yeri bulunmaktadır. 
Beden eğitimi dersindeki empati etkinliklerinde, kendini karşısındakinin yerine koyarak düşünebilmek ve aynı zamanda karşıdakinin hislerini sezinlemeye çalışmak gibi duygusal yönler vurgulanmaktadır. Esas amaç, karşıdakini daha iyi anlayarak ona karşı olumlu bir tutum ve anlayıș geliștirmektir. Anlayıș, ön yargıları gidermekte, saldırganlığı önlemekte ve toplumsal tutumları geliştirmektedir. Başkalarını daha iyi anlamaya yönelik "empati" çalışmaları, giderek, öğrencilerin kendilerini daha iyi anlamasını sağlamaktadır (Yıldıran, 2005). Öte yandan, var olan ulusal literatür incelendiğinde, beden eğitimi ve sporda bakış açısı alma becerilerini geliştirmeye yönelik araştırmaların sınırlı sayıda olduğu görülmektedir. Bakış açısı alma becerilerinin bireylerin bütünsel gelişimlerinde oldukça önemli bir yere sahip olduğu düşünüldüğünde, bu konudaki araștırmalar kritik bir öneme sahiptir. Bu bilgiler ışığında bu araştırma, öncelikle beden eğitimi ve sporda perspektif alma etkinliklerini içeren bir program oluşturma ve oluşturulan bu programın öğrencilerin bakış açısı alma becerileri üzerine olan etkisini incelemek amacıyla gerçekleştirilmiştir.

\section{Yöntem}

Araştırmanın Modeli

Beden eğitimi ve sporda perspektif alma etkinliklerinin lise öğrencilerinde bakış açısı alma becerileri üzerine etkisini değerlendirmek üzere yapılan bu çalışmada tek gruplu ön test-son test olmak üzere deneysel araştırma deseni kullanılmıştır. Bu deneysel modelde tek bir gruptan ölçümler alınır ya da çalışma öncesinde-sonrasında grup üzerinde gözlem yapılır (Fraenkel ve Wallen, 2006). Grup ya da gruplara öntest, çalışma başlamadan verilir. Çalışma sonrasında ise aynı test son-test olarak verilir (Sönmez ve Alacapınar, 2013). Eşitlenmiş bir karşılaştırma grubuna erişim mümkün olmadığında, bu desen kullanılarak bazı bilgilere ulaşılabilir (Christensen, Johnson ve Turner, 2015).

\section{Araştırma Grubu}

Araştırmanın çalışma grubunu, 2017-2018 eğitim-öğretim yılı birinci yarıyılında Konya ili Cihanbeyli ilçesindeki bir anadolu lisesinde öğrenim görmekte olan 9. sınıf öğrencileri oluşturmuştur. Öğrencilerin bakış açısı alma becerilerini belirlemek için Kişilerarası Tepkisellik İndeksi'nin "perspektif alma alt boyutu" dört şubeden oluşan toplam 92 öğrenciye araştırmacı tarafından uygulanmıştır. Bakış açısı alma becerisi en düşük puanlara sahip olan 14'ü kız 8'i erkek olmak üzere toplam 22 öğrenciden oluşan şube araştırma grubu olarak kolay ulaşılabilir amaçlı örnekleme yöntemiyle belirlenmiştir.

\section{Veri Toplama Araçları:}

Kişilerarası Tepkisellik İndeksi (IRI)

Bu araştırmada bakış açısı alma beceri düzeyleri Davis (1983) tarafından geliştirilen ve Türkçe'ye uyarlaması Engeler (2005) tarafindan yapılan Kişilerarası Tepkisellik İndeksi'nin (Interpersonal Reactivity Index: IRI) perspektif alma alt boyutu ile ölçülmüştür. Davis'in Kişilerarası Tepkisellik İndeksi toplam 21 maddeye sahip beşli likert tipi bir ölçektir (1= beni hiç tanımlamıyor, 2= beni çok az tanımlıyor, 3= beni kısmen tanımlıyor, 
4= beni oldukça tanımlıyor, 5= beni tam olarak tanımlıyor). Ölçek her biri 7 maddelik 4 alt boyuttan meydana gelmektedir. Bu çalışmada çalışmayı yansıtan 4 alt boyuttan sadece perspektif alma alt boyutu kullanılmıştır. Perspektif alma karşıdaki kişinin ruhsal olarak bakış açısını kişinin kendisinin kabullenebilme düzeyini ölçmektedir (örn: Arkadaşlarımın açısından olayların nasıl gözüktüğünü düşünerek onları daha iyi anlamaya çalışırım.). Bu alt boyut empatinin bilişsel özelliğini yansıtmaktadır. Kişiselarası tepkisellik indeksinin perspektif alma alt boyutunun cronbach alfa katsayısı ön test için 0.62 , son test için 0.70 olarak hesaplanmıştır.

\section{Empati-Perspektif Alma Eğitim Programı}

Beden eğitimi ve sporda Empati-Perspektif Alma Eğitim Programı, Yılmaz-Yüksel (2003) tarafından hazırlanan "Empati Eğitim Programı"ndan faydalanılarak araștırmacılar tarafından beden eğitimi ve spor ortamına uygun olacak şekilde tasarlanmıştır. Beden eğitimi ve spor için hazırlanmış olan “Empati-Perspektif Alma Eğitim Programı”ında 14-15 yaş lise öğrencilerinin bakış açısı alma becerileri üzerine "Empati-Perspektif Alma Eğitim Programı"nın etkisi baz alınmıștır. Beden Eğitimi ve Sporda Empati-Perspektif Alma Eğitim Programı öğrencilerin sportif ortam ya da etkinlikler sırasında kendilerinin algısal, düşünsel ve duygusal olarak farkına varırken, karşılarındaki kişilerin de algısal, duygusal ve düşünsel olarak kendilerinden farklı olabileceklerini anlamalarını hedefleyen bir programdır. Bunun yanı sıra belli durumlar karşısında karşıdakinin bakış açısını anlayabilmelerini amaçlamaktadır.

Empati-Perspektif Alma Eğitim Programı hazırlanırken, literatür taraması sonucunda, bakış açısı alma becerilerini geliştirme üzerine yapılan çalışmaların tek yönlü olduğu saptanarak, farklı etkinlik türlerini içeren bir program hazırlanması amaçlanmıştır. Hazırlanan programdaki etkinlikler öğrencilerin algısal, bilişsel ve duyuşsal bakış açısı alma becerilerini geliştirmek amacıyla hazırlanarak uygulanmıştır. Eğitim programı 10 hafta boyunca süren oturumlardan oluşmak üzere, haftada bir gün ve 45 dakika süreli olarak uygulanmıştır.

\section{Empati-Perspektif Alma Eğitim Programı Kazanımları}

1. Farklı duygu ve yüz ifadelerini tanıma

2. Kendi duygularını tanıyabilme ve ifade edebilme

3. Verilen bir durumda kişilerin hangi duyguları yaşayabildiklerini fark edebilme

4. Kişilerin aynı olaylar karşısında farklı duygular yaşayabileceğini anlayabilme

5. Duyguları ifade etme becerisi geliştirme

6. Kendini karşısındakinin yerine koyabilme

7. Dinleme becerisini geliştirebilme

8. Karşısındaki kişinin bakış açısını alabilme 


\section{Empati-Perspektif Alma Ĕ̆itim Programının Haftalık Uygulama Süreci}

1. Oturum: Eğitim alan öğrencilerin birbiriyle tanıșmalarının sağlanması amacıyla isim zinciri etkinliği yapılmıştır. Soru-cevap etkinliğiyle öğrencilerin empati ve perspektif alma ile ilgili hazır bulunuşluklarını belirlenmiştir. Ön bilgi yoklamasıyla beraber empati ve perspektif almanın tanımları yapılarak, süreçle ilgili bilgilendirmeler yapılıp, eğitim oturumlarında uyulması gereken kurallar belirtilerek ön test uygulanmıştır.

2. Oturum: Öğrencilere insanların farklı durumlar karşısında farklı duygular yaşayabildiklerinden bahsedilerek, farklı duyguların (mutluluk, kızgınlık, öfke, korku, üzüntü) neler olduğu anlatılmıştır. Duygu ve yüz ifadeleri arasındaki değişiklikleri gözlemleyip, algısal farkındalığı artırmak için farklı spor dallarıyla uğraşan sporcuların spor esnasındaki yüz ifadelerini içeren fotoğraflar gösterilerek yüz ifadelerinden hangi duyguları hissettikleri sorulmuştur. Duygu durumlarıyla ilgili konuşma balonlarının olduğu fotoğraflar ev ödevi olarak verilmiştir.

3. Oturum: Öğrencilerin kendi duygularının ve yüz ifadelerinin farkına varmalarını sağlamak amacı ile senaryo canlandırma etkinliği yapılmıştır. Canlandırılan senaryonun öğrencilerde uyandırdığı duygular ele alınarak, durumla ilgili tartışmaları sağlanmıştır.

4. Oturum: Öğrencilere, aynı olayda farklı kişilerin farklı duygular yaşayabileceğinin farkına varmalarını sağlayacak duygu durumlarını içeren senaryolar verilmiştir. Hem senaryoyu canlandırmak için seçilen öğrencilere hem de izleyicilere senaryonun canlandırılması sırasında ne hissettikleri ve bu duyguları nasıl anladıkları sorulurmuştur. Ev ödevi olarak öğrencilerin beden eğitimi derslerinde ve spor etkinliklerinde çevredeki kişileri gözlemleyerek hangi durumlarda üzgün, kızgın, mutlu ve korku duygusunu yaşadıklarını gözlemlemeleri istenmiştir.

5. Oturum: Bir önceki hafta verilen ödevlerin tartışması yapılarak, o hafta yapılanlar kısaca gözden geçirilmiștir. Verilen durumlarda bireyler arasında algısal farklılıklar olabileceğinin farkına varmalarını sağlamak amacıyla, öğrencilere eğitmen tarafından oluşturulan senaryoda kişilerin aynı durumda farklı algı durumlarına sahip olabilecekleri gösterilerek, tartışılmıştır.

6. Oturum: Öğrencilerin kendi duygularının farkına varmaları ve ifade edebilmelerini sağlamak amacıyla, önceden hazırlanmış durumları kendi duygularıyla anlatmaları istenmiştir.

7. Oturum: Sağlıklı bir şekilde perspektif alabilmek için dinleme becerisini geliştirmek amacıyla, öğrencilerin yaşadıkları olayları arkadașlarına ilk seferde duygu ve yüz ifadesi kullanmadan, ikinci seferde duygu ve yüz ifadesi kullanarak anlatmaları istemiştir. Her duygu durumunun ardından öğretmen öğrencilere arkadaşlarının nasıl hissetmiş olabileceğine dair sorular sormuştur. Öğrencilerden dinledikleri olayı arkadaşlarının duygu durumu ve bakış açısına göre ifade etmeleri sağlanmıştır. 
8. Oturum: Öğrencilerin kendilerini karşısındaki kişilerin yerine koyabilme becerisini geliştirip farklı bakış açısı alabilme becerilerini geliştirmek amacıyla paralimpik oyunlarla ilgili video ve röportajlar izletilmiştir. Video ve röportajdaki sporcuların bakıș açısından bakabilen öğrenci tepkileri sözel olarak pekiştirilmiştir.

9. Oturum: Öğrencinin doğru iletişim kurabilmesi için uygun bakış açısı alabilmesini geliştirmek amacıyla çeşitli senaryolar verilmiştir. Öğrencilerden, verilen senaryonun uygun bakış açısına göre yorumlanması istenmiş ve senaryoda verilmesi gereken uygun bakış açısı kontrol edilmiştir.

10.Oturum: Eğitim sonucunda öğrencilerdeki değişimin belirlenmesi amacıyla son test uygulanarak eğitim tamamlanmıştır.

\section{Verilerin İstatistiksel Analizi}

$\mathrm{Bu}$ çalışmada elde edilen veriler IBM SPSS 22 paket programı ile analiz edilmiştir. Değişkenlerin normal dağılımdan gelme durumları incelenirken birim sayıları nedeniyle Shapiro Wilk's'den yararlanılmıştır. Gruplar arası farklılıklara bakılırken değişkenlerin normal dağılım göstermemesi nedeniyle Mann Whitney U testi kullanılmıştır. İki bağımlı değişken arası farklılığa bakılırken değişkenlerin normal dağılım göstermemesi nedeniyle Wilcoxon testi kullanılmıştır. Araştırma kapsamında istatistiksel anlamlılık düzeyi p<0.05 olarak alınmıştır.

\section{Bulgular}

Beden eğitimi ve sporda perspektif alma etkinliklerinin lise öğrencilerinde bakış açısı alma becerileri üzerine etkisini incelemek amacıyla yapılan bu araștırmadan elde edilen verilerin analiz yapılarak, araştırma bulguları tablolar halinde gösterilmiştir.

Tablo 1. Eğitim öncesi ve sonrası perspektif alma puanları arasındaki farklılığa ilișkin Wilcoxon testi

\begin{tabular}{lccccccccc}
\hline Perspektif alma & $\mathbf{N}$ & $\overline{\mathbf{X}}$ & $\begin{array}{c}\text { Ortanca } \\
\text { değer }\end{array}$ & Min & Max & SS & $\begin{array}{c}\text { Sira } \\
\text { Ort. }\end{array}$ & $\mathbf{z}$ & $\mathbf{p}$ \\
\hline Ön test puanı & 22 & 16.7 & 16 & 6 & 24 & 5 & 4.8 & \\
\hline Son test puanı & 22 & 22.1 & 22 & 12 & 28 & 3.9 & 11.5 & & \\
\hline
\end{tabular}

Öğrencilerin ön test skorları ile son test skorları kıyaslandığında perspektif alma puanları bakımından test skorları arasında istatistiksel anlamlılık tespit edilmiştir $(p<0.05)$. Eğitim sonrası perspektif alma skoru eğitim öncesi perspektif alma skoruna göre anlamlı seviyede yüksektir (sırasıyla 16.7; 22.1).

Tablo 2. Ön test-son test sıralama değerleri

\begin{tabular}{lllcc}
\hline & & $\mathbf{N}$ & Siralar Ortalaması & Siralar Toplamı \\
\cline { 2 - 5 } Ön test-Son test & Negatif sıralar & $3^{\mathrm{a}}$ & 4.83 & 14.50 \\
\cline { 2 - 5 } & Pozitif sıralar & $17^{\mathrm{b}}$ & 11.50 & 195.50 \\
\cline { 2 - 5 } & Eşit & $2^{\mathrm{c}}$ & & \\
\cline { 2 - 5 } & Toplam & 22 & & \\
\hline
\end{tabular}


Sıralama tablosu verileri incelendiğinde ön test sonuçlarından 3 gözlem puanının son test sonuçlarından yüksek olduğu, son test sonuçlarından 17 gözlem puanının ön test puanlarından yüksek olduğu, 2 sonucun ise eșit olduğu anlaşılmaktadır.

Tablo 3. Perspektif alma skorlarının cinsiyetler arasındaki farklılığa göre eğitim öncesi ve sonrası Mann Whitney U testi sonucu

\begin{tabular}{llccccccccc}
\hline Perspektif alma & & $\mathbf{N}$ & $\overline{\mathbf{X}}$ & $\begin{array}{c}\text { Ortanca } \\
\text { değer }\end{array}$ & Min & Max & SS & $\begin{array}{c}\text { Sira } \\
\text { Ort. }\end{array}$ & $\mathbf{z}$ & $\mathbf{p}$ \\
\hline \multirow{3}{*}{ Ön test puanı } & Kız & 14 & 16.3 & 15.5 & 10 & 23 & 4.3 & 10.6 & \\
& Erkek & 8 & 17.3 & 18.5 & 6 & 24 & 6.2 & 13 & -0.822 & 0.411 \\
& Toplam & 22 & 16.7 & 16 & 6 & 24 & 5 & & & \\
\hline \multirow{3}{*}{ Son test puanı } & Klz & 14 & 21.2 & 21.5 & 12 & 27 & 4.2 & 10. & & \\
& Erkek & 8 & 23,8 & 24 & 21 & 28 & 2,9 & 14 & -1.378 & 0.168 \\
& Toplam & 22 & 22,1 & 22 & 12 & 28 & 3,9 & & & \\
\hline
\end{tabular}

Katılımcıların, ön test skorları ile son test skorları cinsiyete göre değerlendirildiğinde cinsiyetler arası farkın anlamlı olmadığı görülmektedir ( $p>0.05)$. Yukarıdaki tablo incelendiğinde, ön test skorları ile son test skorlarında, erkeklerin (sırasıyla \%17.3 ve 23.8) kızlardan (\%16.3 ve \%21.2) daha yüksek puan aldıkları görülmektedir.

\section{Tartışma}

Beden eğitimi ve sporda perspektif alma etkinliklerinin öğrencilerin bakış açısı alma becerileri üzerine etkisinin incelendiği bu araştırmanın sonuçları, "perspektif alma" etkinlikleri bakımından eğitim öncesi ve eğitim sonrası puanları kıyaslandığında anlamlı bir farklılık ortaya koymaktadır. Beden eğitimi ve sporda öğrencilerin okul içi etkinlikler ya da müsabakalar sırasında takım arkadaşlarını cesaretlendirme, iş birliği, yardımlaşma, rakibi tebrik etme, yenilgiyi kabullenebilme gibi olumlu davranışlar olarak nitelendirdiğimiz prososyal davranışları destekleyebilmek ve rakibi aldatma, kurallara aykırı oynama, akran zorbalığı gibi olumsuz olarak nitelendirilen antisosyal davranışları da en aza indirebilmek için empati becerisinin geliştirilmesi önem arz etmektedir. SezenBalçıkanlı ve Sezen (2019) de, genç çim hokeyi sporcularının antisosyal-prososyal davranışları ve empati arasındaki ilişkiyi inceledikleri çalışmalarında empatinin prososyal davranışlarla pozitif, antisosyal davranışlarla negatif yönlü korelasyon saptamışlardır. Dolayısıyla kimlik biçimlendirme sürecinin yaşandığı ergenlik döneminde gençlere beden eğitimi ve spor yoluyla öğretmenler ve antrenörler tarafından verilecek empati eğitimi hayati önem taşımaktadır. Bunun yanı sıra empati eğitiminde etkin rol oynayan öğretmen ve antrenörlerin, empatik becerileri sürecin etkinliğinde önemli bir değişken olarak vurgulanmaktadır (Aktaş ve Sezen-Balçıkanlı, 2018).

Mevcut çalışmanın bulgularına göre, kızlar ile erkekler arasında bakış açısı alma becerisi açısından fark istatistiksel olarak anlamlı değildir. İlgili literatür incelendiğinde, kız çocukların erkek çocuklara kıyasla daha yüksek oranda empati becerilerine sahip olduklarını gösteren araştırmalara rastlanmaktadır (Davis, 1983; Eisenberg ve Lennon, 1983; Feshbach ve Roe, 1968; Ünüvar, 2006). Demirci (2010) tarafindan bağımsız anaokullarına devam eden 4-6 yaş arası çocuklarının bakış açısı alma becerileri ile görsel 
algı becerileri arasındaki ilişkinin incelendiği çalışmada, önceki literatür bulgularıyla paralel olarak kız çocuklarının erkeklere kıyasla daha yüksek oranda empati becerileri sergilediği bulunmuştur. Ek olarak, 60-72 ay grubundaki çocukların bakış açısı alma becerilerinin incelendiği bir başka çalışmada (Bal, 2013), cinsiyetin bakış açısı alma becerileri üzerinde azımsanamayacak bir fark oluşturduğu tespit edilmiştir. Çalışmalarda kadınların erkeklere oranla yüksek empatik skor elde etmesinin sebebinin kadınların daha fazla duygusal tepki göstermesi olduğu düşünülmektedir (Dökmen, 2005). Var olan literatürle kıyaslandığında, bu çalışmadan farklı bir sonuç alınmasının nedeni olarak katılımcıların yaş grubunun, kritik bir dönem olan ergenlik çağı içerisinde olmaları gösterilebilir. Çünkü çalışmalar, yaşın bakış açısı alma becerisini etkilediğini ve yaş ilerledikçe bakış açısı alma becerisinin arttığını göstermektedir (Değirmenci, 2014; Flavell, 1974; Kurdek ve Rodgon, 1975).

Diğer bir yandan, mevcut çalışmanın bulgularını destekleyen araştırmalar da bulunmaktadır. Oğuz (2006) tarafından yapılan bir çalışmada, cinsiyet değişkeninin 72 aylık çocukların bakış açısı alma becerisi üzerinde bir etkisinin olmadığı bulunmuştur. Yine benzer şekilde, Yılmaz'ın (2012) çalışmasında, 60-72 aylık çocukların cinsiyet değişkenine göre duyguları anlama becerileri incelenmiş ve bu becerilerin cinsiyete göre farklılık göstermediği belirlenmiştir. Tüm bu çalışmalar ışı̆̆ında, cinsiyetin okul öncesi dönem çocuklarının bakış açısı alma becerileri üzerinde etkisi olduğu düşünülürken, lise dönemi üzerinde etkisi olmadığı düşünülebilir. Çünkü çocukluk dönemine kıyasla ergenlik döneminde ergenin baş etmesi gereken biyopsikososyal farklılaşma sayısı artmaktadır. Bunlardan biyolojik olarak ergenin vücudunda birtakım değişiklikler ortaya çıkmaktadır ve ergen bu değişikliklere ayak uydurmak zorundadır. Zamansal olgunlaşma ile beliren bilişsel yeterlilikler, ergeni kendisiyle ilgili inceleme yapmasının yanı sıra çevresini bu sürece dahil etme durumunda bırakmaktadır. Olgunlaşmaya paralel olarak ortaya çıkan bilişsel yetiler ergeni hem kendiyle hem de çevresiyle ilgili yeni değerlendirmeler ve soyutlamalar yapmaya yönlendirir. Ergenlik döneminde "Ben kimim?" sorusuna yanıt bulmaya çabalayan ergen için bu çağın gelişimsel görevi olan, kimlik duygusu öncelikli olmaktadır (Çuhadaroğlu ve Sonuvar, 1992). Tüm ergenlerin kimlik biçimlendirme süreci aynı dönem içerisinde gerçekleştiğinden, cinsiyetler arasında fark bulunamamış olabilir. Örneğin, Köksal (2000) tarafından yapılan, müzik eğitimi almanın çeşitli değişkenlere göre ergenlerin empatik beceri ve uyum düzeylerinin incelendiği araştırmada cinsiyetin empatik beceri alma üzerinde etkisi olmadığı saptanmıştır. Benzer şekilde Kumbaroğlu (2013)'nun, spor yapan ve yapmayan lise öğrencilerinin empatik eğilim seviyelerini çeşitli sosyo-demografik özelliklere göre karşılaştırdığı çalışmasında, öğrencilerin cinsiyet değişkenine göre empatik eğilim düzeylerinde anlamlı bir skor bulunamamıştır. Yine bu çalışmaya ek olarak, Şahin (2018) tarafından spor lisesi öğrencileri üzerinde yapılan bir çalışmada benzer bir sonuç bulunmuş ve öğrencilerin cinsiyete göre empatik eğilimlerinde bir farklılaşma olmadığı sonucuna varılmıştır. Korkmaz, Şahin, Kahraman ve Öztürk (2001) bu durumu kişilik özellikleriyle açılklamaktadır. Yörükoğlu'na göre (1993), kişilik kavramı bir bireyin bulunduğu ortama ayak uydurabilmesi için geliştirdiği ve kişiyi bu özellikleriyle diğerlerinden ayıran nitelik ve davranışlar bütünü, insanı başkalarından ayıran özelliklerin tümü ve çevresine uyum sağlamak için geliştirdiği davranış biçimleri olarak 
tanımlanmaktadır. Ayrıca kişilik oluşumunun yaşamla birlikte başlamasından dolayı bu aşamalar; altı yaşlarına doğru kişiliğin çizgilerinin belirmesi ve kesin şeklini ergenliğin son döneminde bulması șeklinde sıralanmaktadır. Kişiliğin bireyin çevresiyle sürekli etkileşimi ve uyumu sonucu oluşması ve dolayısıyla bu sürecin uzun olması kișiliğin kolayca değişmeyeceğinin göstergesi olmaktadır. Ergenlerin kişilikleri, gelişim görevleri ile aktif olarak ilgilendikçe yetkinleșir ve bunlardan en önemlisi kimlik gelişimidir (Grotevant, 1995). Toplumsal fark aranmaksızın, ergenlik döneminin diğer dönem gelişmelerinden farklı olduğu gerçeği duygu, düşünce, eylem ve davranışlara yansımakta ve bunların bu döneme özel olduğu yadsınamaz gerçekler arasındadır (Öztürk, 2007). Bu döneminin psikolojik işaretlerine bakıldığında ölçüsüz, sağlıksız ve karmaşı bir görünümle karşılaşılmaktadır. Ani öfke patlamaları, içe kapanıklık, ani sevinç ve üzüntü, kızgınlık, sinirlilik, bilinçsizce hareketler, birden tepki gösterme gibi davranışları sergileyen bir insana konulacak teşhis, 'ruh sağlığı bozuk' şeklinde olacaktır (Yörükoğlu, 1993). Tüm bu bilgiler ışığından hareketle kimlik duygusunun, ergenlik döneminde kazanılması gereken psikososyal gelişim görevi olmasından ve kimlik biçimlendirme sürecinin aynı dönem içerisinde gerçekleşmesi, cinsiyetler arası fark saptanamamasının nedeni olarak gösterilebilir.

Beden eğitimi ve spor ortamında öğrencilerin bakış açısı alma becerilerini geliştirmek için oluşturulan perspektif alma etkinlikleri içerisinde bilgi verme, rol oynama, öykü yaratma, drama, senaryo oynama, ödev verme ve geri bildirim gibi etkinliklere yer verilmiştir. Mevcut çalıșma bulgularının, beden eğitimi ve sporda perspektif alma etkinliklerinin öğrencilerin bakış açısı alma becerilerini geliştirdiği görülmektedir.

İlgili literatür incelendiğinde, empati eğitim programlarının daha çok okul öncesi eğitimi alan çocukların bakış açısı alma becerileri üzerine yoğunlaştığı görülmektedir. Ancak, literatürde beden eğitimi ve sporda perspektif alma eğitimi ile ilgili herhangi bir çalışmaya rastlanmamaktadır. Beden eğitimi ve spora küçük yaşlarda başlanılması nedeniyle, perspektif alma eğitim programının okul öncesi dönem çocukları üzerinde yapılacak olan araştırmalardaki boşluğu da dolduracağı ve birbirlerini tamamlar nitelikte olacağı düşünülmektedir. Ayrıca, Yılmaz-Yüksel (2003) tarafından ilkokul öğrencileri üzerinde yapılan araştırmada da empati eğitim programının öğrencilerin empatik becerilerini artırdığı bulgusuna ulașılmıştır. Mevcut araştırmanın eğitim programını oluştururken, Yılmaz-Yüksel'in (2003) yapmış olduğu empati eğitim programından yararlanılmıştır. $\mathrm{Bu}$ araştırma bulguları mevcut araştırma bulgularıyla paralellik göstermektedir. Buradan yola çıkarak araştırmalar birbirlerini destekler niteliktedir.

Literatür taraması sonucu kullanılan teknik ve alıştırmalarla, mevcut araştırmada geliştirilen perspektif alma eğitim programında kullanılan teknik ve alıştırmalar da (bilgi verme, rol oynama, öykü yaratma, model alma, video izleme, ödev verme, geri bildirim gibi) birbiriyle benzerlik göstermektedir. 


\section{Sonuç ve Öneriler}

Öğrencilerin bakış açısı alma becerileri üzerine yapılan bu araştırma sonuçları, beden eğitimi ve sporda perspektif alma etkinliklerinin öğrenciler üzerinde olumlu yönde etkili olduğunu göstermektedir. Beden eğitimi ve sporda perspektif alma etkinliklerinin, ders içerisinde, sportif etkinlikler ve müsabakalar sırasında öğrencilerin önce kendilerinin ve daha sonra başkalarının duygularını fark etmelerini, kişilerin aynı olay ve durumlar karşısında farklı tepki ve duygular içerisinde olabileceklerini anlamalarına yardımcı olacak etkinlikleri kapsamaktadır. Araştırma sonuçları dikkate alındığında, Perspektif Alma Eğitim Programı'nın lise öğrencilerinin bakış açısı alma becerileri üzerinde anlamlı etkisinin olduğu görülmektedir. Literatür taraması sonucu benzer etkinlikleri içeren programların denendiği daha önce yapılmış olan araștırmalar, bu çalışma bulgularıyla benzer nitelikte ve bakış açısı alma becerilerinin geliştirebilirliğini göstermektedir. Ping (2005)'in çocuklar üzerinde yapmış olduğu araştırmasında, çocukların bakış açısı alma becerileri üzerinde hayali oyunların etkisini incelemiștir. Bu hayali oyun ve öykü etkinliklerinde, çocuklardan olay örgüsüne bağlı kalarak yeniden canlandırma yapmaları istenmiştir. Hayali öykü ve oyunların bakış açısı alma becerilerini geliştirdiği bulunmuştur. Akın ve Önder (2003) yaptıkları araştırmalarında, bakış açısı alma becerileri üzerine eğitici drama faaliyetlerinin katkı sağladığını saptamışlardır. Şener (1996) yaptığı araştırmasında, çocuklarda bakış açısı alma becerileri üzerinde dramatik oyunun pozitif etkisi olduğunu belirlemiştir. Bu araştırmalarda kullanılan tekniklerle, mevcut araștırmada geliştirilen perspektif alma etkinlikleri, bakış açısı alma becerilerini geliştirme noktasında birbirlerini destekler niteliktedir.

Sonuç olarak, beden eğitimi ve spor derslerinde uygulanacak perspektif alma etkinliklerinin öğrencilere bakış açısı alma becerisi kazandırdığını söylemek mümkündür. Perspektif alma etkinliklerinin, öğrencilerin olaylara, karşısındakinin bakış açısından bakabilme becerisi sağlayacağı ve bu bağlamda akran zorbalığı, arkadaşlarına yönelik fiziksel ya da psikolojik şiddet, antisosyal davranışlar gibi olumsuz davranış özelliklerini en aza indirmek konusunda da katkı sağlayacağı düşünülmektedir.

$\mathrm{Bu}$ araştırmada, beden eğitimi ve sporda perspektif alma etkinliklerini içeren bir program oluşturma ve oluşturulan bu programın 14-15 yaş grubu lise öğrencilerinin bakış açısı alma becerileri üzerine etkisi araştırılmıştır. Gelecekte yapılacak araştırmalarda ise farklı yaş gruplarında ilköğretim ve ortaöğretim düzeyindeki ögrencilerin beden eğitimi ve sporda perspektif alma etkinliklerinin bakış açısı alma becerilerine etkisi sınanabilir.

Perspektif alma eğitim programının kalıclığı ve etkililiğini izlemek üzere okul öncesi yıllarda başlanan boylamsal araştırmalar yapılabilir. Beden eğitimi öğretmenleri için bakış açısı alma becerisine yönelik programlar düzenlenerek bu programların etkisi araștırılabilir. 


\title{
Yazar notu:
}

Bu araştırma 2019 yılında yapılan "Beden eğitimi ve sporda perspektif alma etkinliklerinin lise öğrencilerinin bakış açısı alma becerileri üzerine etkisi” başlıklı yüksek lisans tezinin bir bölümüdür.

Kullanılmak istendiği takdirde "Perspektif Alma Eğitim Programı" araştırmacılardan temin edilebilir.

\section{Çıkar Çatışması}

$\mathrm{Bu}$ makalenin yayınlanmasıyla ilgili yazarlar arasında herhangi bir çıkar çatışması bulunmamaktadır.

\section{Yazar Katkıları}

Araştırma Fikri: GSB; Araştırma Tasarımı: GSB, MI; Verilerin Analizi: MI; Makale Yazımı: MI; Eleştirel İnceleme: GSB

\author{
Yazışma Adresi (Corresponding Address): \\ Merve IŞIKCI \\ Yaşar Doğu Ortaokulu, MEB, ANKARA \\ ORCID: 0000-0003-1625-7903 \\ E-posta: isikcimerve@gmail.com
}




\section{Kaynaklar}

1. Akın, Y. ve Önder, A. (2003, Ekim). Altı yaş grubu çocuklarında başkasının bakış açısını alma yetisi üzerinde eğitici drama programının ve aile tutumlarının etkisi. OMEP Dünya Konseyi Toplantısı Bildiri Kitabı, Kuşadası.

2. Aktaş, İ. ve Sezen-Balçıkanlı, G. (2018). The levels of empathy and social problem solving skills of physical education and sports teacher candidates. Journal on Educational Psychology, 11(4), 814.

3. Aslan, D. (2017). Okul öncesi dönem çocuklarının bakış açısı alma becerilerine empati eğitim programının etkisinin incelenmesi (Yayımlanmamış doktora tezi). Ankara Üniversitesi Fen Bilimleri Enstitüsü, Ankara.

4. Bailey, R. (2006). Physical education and sport in schools: a review of benefits and outcomes. The Journal of School Health, 76(8), 397-401.

5. Bal, 0̈. (2013). Okul öncesi eğitim kurumlarına devam eden 4-6 yaş çocukların kişilerarası problem çözme becerileri ve bakış açısı alma becerileri arasındaki ilişkinin incelenmesi (Yayımlanmamış yüksek lisans tezi). Gazi Üniversitesi Eğitim Bilimleri Enstitüsü, Ankara.

6. Christensen, L. B., Johnson, R. B. ve Turner, L. A. (2015). Araștırma yöntemleri desen ve analiz (Çev. A. Aypay). Ankara: Anı Yayıncılık.

7. Çuhadaroğlu, F. ve Sonuvar, B. (1992). Adolesanlarda depresyon. Nöropsikiyatri Arşivi, 29,14550 .

8. Davis, M. H. (1983). Measuring individual differences in empathy: Evidence for a multidimentional approach. Journal of Personality and Social Psychology, 44(1), 113-126.

9. Değirmenci, G. Y. (2014). Ankara il merkezinde bağımsız anaokullarına devam eden 48-60 aylık çocukların görsel algı becerileri ile bakış açısı alma becerileri arasındaki ilişki (Yayımlanmamış yüksek lisans tezi). Gazi Üniverstesi Eğitim Bilimleri Enstitüsü, Ankara.

10. Demirci, A. (2010). Görsel algı eğitiminin beş-altı yaş çocuklarının görsel algı gelişimlerine etkisi (Yayımlanmamış doktora tezi). Gazi Üniversitesi Eğitim Bilimleri Enstitüsü, Ankara.

11. Dervent, F., Arslanoğlu, E. ve Şenel, Ö. (2010). Lise öğrencilerinin saldırganlık düzeyleri ve sportif aktivitelere katılımla ilișkisi. Uluslararası İnsan Bilimleri Dergisi, 7(1) 521-533.

12. Dökmen, Ü. (2005). Çocukken hayali arkadaşlarımla oynardım. Arzu Yağmurlu ile söyleși. Kişisel Gelişim Dergisi, Sayı: Nisan.

13. Dökmen, Ü. (2008). Sanatta ve günlük yaşamda iletişim çatışmaları ve empati. İstanbul: Sistem.

14. Eisenberg, N. ve Lennon, R. A. (1983). Sex differences in empathy and related capacities. Phsychological Bulletin, 91(1), 100-131.

15. Engeler, A. (2005). Psikopati ve antisosyal kişilik bozukluğu (Yayımlanmamış doktora tezi). İstanbul Üniversitesi Adli Tıp Enstitüsü, İstanbul.

16. Feshbach, N. D. ve Roe, K. (1968). Empathy in six-and seven-year-olds. Child Development, 39(1), 133-145.

17. Flavell, J. H. (1974). The development of inferences about others. T. Mischel (ed.), Understanding other persons (pp. 66-116). Blackwell: Oxford.

18. Fraenkel, J. R. ve Wallen, N. E. (2006). How to design and evaluate research in education (6th ed.). New York: McGraw-Hill, Inc.

19. Frick, A., Möhring, W. ve Newcombe, N. S. (2014). Picturing perspectives: Development of perspective-taking abilities in 4-to 8-year-olds. Frontiers in Psychology, 5, 386.

20. George D. ve Mallery, P. (2003). SPSS for Windows step by step: A simple guide and reference. 11.0 update (4th ed.). Boston: Allyn \& Bacon. 
21. Gessmann, R. (1985). Fair Play - Eine wichtige Erziehungsaufgabe und ihre Umsetzung im Sportunterricht. V. Gerhardt, M. Laemmer (Hrsg). Fairness und Fair Play (s. 138-155). Sankt Augustin: Academia-Verlag.

22. Grotevant, H. D. (1995). Kișilik gelişimi. J.F. Adams (Ed.) Ergenliği anlamak (153-184) (Ö. Hakan Ersever, Çev.) B. Onur (Ed.). Ankara: İmge.

23. İlhan, L. (2008). Eğitilebilir zihinsel engelli çocuklarda beden eğitimi ve sporun sosyalleşme düzeylerine etkisi. Kastamonu Eğitim Dergisi, 16(1), 315-324.

24. Kähler, R. (1985). Moralerziehung im Sportunterricht: Untersuchung zur Regelpraxis und zum Regelbewußtsein. Frankfurt a.M., Germany: Verlag Thun, Deutsch.

25. Kaplan, Y. ve Çetinkaya, G. (2010, Nisan). Çocuklar için, bir iletişim ve toplumsallaşma aracı olarak spor. Uluslararası Çocuk ve Spor Kongresi' de sunulan bildiri, Lefkoşa.

26. Klahr, D. (2012). Beyond Piaget: A perspective from studies of children's problem solving abilities. A. Slater and P. Quinn (Eds.), Development psychology: revisiting the classic studies (pp. 56-70). London: Sage Publications.

27. Koçak, İ. ve Sezen-Balçıkanlı, G. (2021). Savunma sporları ve empati: elit sporcularda empati becerilerinin incelenmesi. Gazi Beden Eğitimi ve Spor Bilimleri Dergisi, 26(2), 203-218.

28. Korkmaz, H. N., Şahin, E., Kahraman, M. ve Öztürk, F. (2001, Ekim). Uludağ Üniversitesi Eğitim Fakültesi Beden Eğitimi ve Spor Bölümü öğrencilerinin empatik becerilerinin cinsiyete göre karşılaştırılması. II. Uluslararası Spor Psikolojisi Sempozyumu'nda sunulan bildiri, Ege Üniversitesi, İzmir.

29. Köksal, A. (2000). Müzik eğitimi alma, cinsiyet ve sınıf düzeyi değișkenlerine göre ergenlerin empatik becerilerinin ve uyum düzeylerinin incelenmesi. Hacettepe Üniversitesi Eğitim Fakültesi Dergisi, 18, 99-107.

30. Kumbaroğlu, Z. B. (2013). Spor yapan ve yapmayan ortaöğretim öğrencilerinin empatik eğilim düzeyleri ile benlik saygısı düzeylerinin çeşitli sosyo-demografik özelliklerine göre karşılaştırılması (Yayımlanmamış doktora tezi). Gazi Üniversitesi Sağlık Bilimleri Enstitüsü, Ankara.

31. Kurdek, L. A. ve Rodgon, M. M. (1975). Perceptual, cognitive and affective perspective taking in kindergarten through sixth- grade children. Development Psychology, 11(5), 643-650.

32. Oğuz, V. (2006). Altı yaş grubundaki çocukların bakış açısı alma becerileri ile anne babaların empatik becerilerinin incelenmesi (Yayımlanmamış yüksek lisans tezi). Ankara Üniversitesi Fen Bilimleri Enstitüsü, Ankara.

33. Opstoel, K., Chapelle, L., Prins, F. J., De Meester, A., Haerens, L., van Tartwijk, J. ve De Martelaer, K. (2020). Personal and social development in physical education and sports: A review study. European Physical Education Review, 26(4), 797-813.

34. Özodaşık, M. (2009). Kişilerarası iletişim sürecinde algı-ikna ve empatik iliş̧kiler. İstanbul: Tablet.

35. Öztürk, Z. A. (2007). İlköğretim öğrencilerinde (4., 5., 6., 7. ve 8. sinıflar) dindarlık ile kaygı arasındaki iliş̧ki (Yayımlanmamış yüksek lisans tezi). Çukurova üniversitesi Sosyal Bilimler Enstitüsü, Adana.

36. Piaget, J. (1965). The moral judgment of the child (Translated by Marjorie Gabain). Glencoe, Illinois: The Free.

37. Ping, A. L. S. (2005). A "new" preschool curriculum that puts play on top: Deja vu or second chance? (Doktora tezi). Durham University, Durham.

38. Sezen-Balçıkanlı, G. ve Yıldıran, İ. (2012). Sportspersonship orientation and empathy: a study of professional football players. Journal of Physical Education and Sport, 12(1), 18-24.

39. Sezen-Balçıkanlı, G. (2017). Yarıșma sporlarının ahlaksal amacı. Spor ve Performans Araştırmaları Dergisi, 8(1), 47-52.

40. Sezen-Balçıkanlı, G. (2014). Fair play in professional sports: Sportspersonship orientations of futsal players. FairPlay, Revista de Filosofia, Ética y Derecho del Deporte, 2(1), 33-49. 
41. Sezen-Balçıkanlı, G. ve Sezen, M. (2017). Professional sports and empathy: A relationship between professional futsal players' tendency toward empathy and fouls. Physical Culture and Sport. Studies and Research, 73(1), 27-35.

42. Shima, T., Tai, K., Nakao, H., Shimofure, T., Arai, Y., Kiyama, K. ve Onizawa, Y. (2021). Association between self-reported empathy and sport experience in young adults. Journal of Physical Education and Sport, 21(1), 66-72.

43. Sönmez, V. ve Alacapınar, F. (2013). Örneklendirilmiş bilimsel araştırma yöntemleri. Ankara: Anı Yayıncillk.

44. Şahin, K. (2018). Spor lisesi öğrencilerinin eleștirel düşünme ve empati kurma eğilimlerinin incelenmesi (Yayımlanmamış yüksek lisans tezi). Gazi Üniversitesi Eğitim Bilimleri Enstitüsü, Ankara.

45. Şener, T. (1996). 4-5 yaş anaokulu çocuklarında dramatik oyunun ve inşa oyununun bakış açısı alma becerisine etkisi (Yüksek lisans tezi). Ankara Üniversitesi Sosyal Bilimler Enstitüsü, Ankara.

46. Ünlü, H. ve Aydos, L. (2008). Beden eğitimi dersinde sınıf yönetimi. Uluslararası İnsan Bilimleri Dergisi, 5(1), 1-7.

47. Ünüvar, G. (2006). Okul öncesi eğitim kurumlarına devam eden 4-5 yaş çocuklarında, zenginleștirilmiş Türkçe dil etkinliklerinin bakış açısı alma becerisine ve ifade edici dil düzeylerine etkisinin incelenmesi (Yayımlanmamış yüksek lisans tezi). Selçuk Üniversitesi Sosyal Bilimler Enstitüsü, Konya.

48. Yıldıran, İ. (2005). Fairplay eğitiminde beden eğitiminin rolü. Gazi Beden Eğitimi ve Spor Bilimleri Dergisi, 10(1), 3-16.

49. Yıldırım, R. (2012). Akran zorbalığı. Celal Bayar Üniversitesi Sosyal Bilimler Dergisi, 10(2), 39-51.

50. Yılmaz, E. (2012). 60-72 aylık çocukların sosyal problem çözme becerilerinin duyguları anlama becerileri açısından incelenmesi (Yayımlanmamış yüksek lisans tezi). Selçuk Üniversitesi Sosyal Bilimler Enstitüsü, Konya.

51. Yılmaz-Yüksel, A. (2003). Empati eğitim programının ilköğretim öğrencilerinin empatik becerilerine etkisi (Yayımlanmamış doktora tezi). Ankara Üniversitesi Eğitim Bilimleri Enstitüsü, Ankara.

52. Yörükoğlu, A. (1993). Gençlik çağı: Ruh sağlığı ve sorunlar. (8.Baskı). İstanbul: Özgür

53. Zhao, J., Wang, L., Su, Y. J. ve Chan, R. (2010). 3 to 5 years old children's behavioral and verbal performances in level 1 perspective-taking. Acta Psychologica Sinica, 42(7), 754-767. 
Bu sayfa boş bırakıımıştır. 